\title{
Efficacy and safety of lurbinectedin and doxorubicin in relapsed small cell lung cancer. Results from an expansion cohort of a phase I study
}

\author{
María Eugenia Olmedo $^{1} \cdot$ Martin Forster $^{2} \cdot$ Victor Moreno $^{3} \cdot$ María Pilar López-Criado $^{4} \cdot$ Irene Braña $^{5} \cdot$ Michael Flynn $^{2}$. \\ Bernard Doger $^{3} \cdot$ María de Miguel $^{6}$ • José Antonio López-Vilariño ${ }^{7} \cdot$ Rafael Núñez $^{7} \cdot$ Carmen Kahatt $^{7}$.

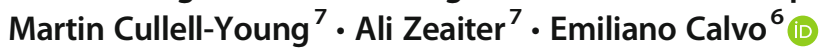

Received: 15 October 2020 / Accepted: 22 October 2020 / Published online: 11 March 2021

(C) The Author(s) 2021

\section{Summary}

Background A phase I study found remarkable activity and manageable toxicity for doxorubicin (bolus) plus lurbinectedin (1-h intravenous [i.v.] infusion) on Day 1 every three weeks (q3wk) as second-line therapy in relapsed small cell lung cancer (SCLC). An expansion cohort further evaluated this combination. Patients and methods Twenty-eight patients with relapsed SCLC after no more than one line of cytotoxic-containing chemotherapy were treated: $18(64 \%)$ with sensitive disease (chemotherapy-free interval [CTFI] $\geq 90$ days) and ten (36\%) with resistant disease (CTFI $<90$ days; including six with refractory disease [CTFI $\leq 30$ days]). Results Ten patients showed confirmed response (overall response rate $[\mathrm{ORR}]=36 \%$ ); median progression-free survival $(\mathrm{PFS})=3.3$ months; median overall survival $(\mathrm{OS})=7.9$ months. ORR was $50 \%$ in sensitive disease (median PFS $=5.7$ months; median OS = 11.5 months) and $10 \%$ in resistant disease (median PFS $=1.3$ months; median OS $=4.6$ months). The main toxicity was transient and reversible myelosuppression. Treatment-related non-hematological events (fatigue, nausea, decreased appetite, vomiting, alopecia) were mostly mild or moderate. Conclusion Doxorubicin $40 \mathrm{mg} / \mathrm{m}^{2}$ and lurbinectedin $2.0 \mathrm{mg} / \mathrm{m}^{2}$ on Day $1 \mathrm{q} 3 \mathrm{wk}$ has shown noteworthy activity in relapsed SCLC and a manageable safety profile. The combination is being evaluated as second-line therapy for SCLC in an ongoing, randomized phase III trial. Clinical trial registration www.ClinicalTrials.gov code: NCT01970540. Date of registration: 22 October, 2013.

Keywords Lurbinectedin $\cdot$ PM01183 $\cdot$ Small cell lung cancer $\cdot$ Phase I study

Emiliano Calvo

emiliano.calvo@startmadrid.com

1 Hospital Ramon y Cajal, Madrid, Spain

2 University College of London Hospital and UCL Cancer Institute, London, UK

3 START Madrid - FJD (Hospital Fundación Jiménez Díaz), Madrid, Spain

4 M.D. Anderson Cancer Center, Madrid, Spain

5 Hospital Universitari Vall d'Hebron, Barcelona, Spain

6 START Madrid - HM CIOCC, Hospital Madrid Norte Sanchinarro, Madrid, Spain

7 Pharma Mar, S.A., Colmenar Viejo, Madrid, Spain

\section{Introduction}

Lurbinectedin is a selective inhibitor of oncogenic transcription that binds preferentially to guanines located in the GCrich regulatory areas of DNA gene promoters $[1,2]$. By preventing binding of transcription factors to their recognition sequences, the drug inhibits oncogenic transcription and leads to tumor cell apoptosis [3]. Lurbinectedin also affects the tumor microenvironment landscape by inhibiting activated transcription in tumor-associated macrophages [4].

Studies in mice found antitumor activity for lurbinectedin against different models of xenografted human-derived tumors. In the first-in-human (FiH) study, single-agent lurbinectedin showed antitumor activity in patients with advanced solid tumors (pancreatic cancer, soft tissue sarcoma, melanoma) [5]. The combination of doxorubicin and lurbinectedin resulted in significantly stronger antitumor 
effect compared to either drug alone in mice bearing xenografted small cell lung cancer (SCLC) tumors, with additive and sometimes synergistic effects [6]. This improved activity led to the conduct of a phase I trial to evaluate this combination of doxorubicin and lurbinectedin in selected advanced solid tumors, including relapsed SCLC. The recommended dose (RD) for the combination was defined at doxorubicin $50 \mathrm{mg} / \mathrm{m}^{2}$ and lurbinectedin $4.0 \mathrm{mg}$ flat dose (FD) on Day 1 every three weeks (q3wk) [7]. Promising antitumor activity was found in second-line SCLC and endometrial cancer during dose escalation. However, $88 \%$ of patients treated at this RD had grade 3/4 neutropenia regardless of relationship. As a result, the combination was further evaluated in an expansion cohort at a lower doxorubicin dose to reduce the incidence of potentially severe myelosuppression. In addition, the lurbinectedin dose was transformed to a body surface area (BSA)-based dose following the finding, in a logistic regression analysis of pooled data from phase II trials with singleagent lurbinectedin, that patients with the lowest BSA values could have a greater possibility of developing grade 3/4 thrombocytopenia. This expansion cohort only enrolled patients with advanced SCLC to be treated as second-line therapy and patients with endometrial cancer. Due to the relevance of the antitumor activity observed in this cohort, the results shown here are focused on advanced SCLC patients.

\section{Patients and methods}

\section{Eligibility criteria}

Eligible patients were aged $\geq 18$ years with confirmed SCLC treated with no more than one prior line of cytotoxiccontaining chemotherapy regimen for advanced disease (other than anthracyclines); with documented disease progression during or immediately after last therapy; who had recovered from previous toxicities; $\geq 3$ weeks since last anticancer therapy; Eastern Cooperative Oncology Group performance status $\leq 2$; normal left ventricular ejection fraction (LVEF); and adequate bone marrow, hepatic and renal function, including albumin $\geq 3.0 \mathrm{~g} / \mathrm{dL}$.

Patients were excluded if they had symptomatic progressive or corticosteroid-requiring brain metastases/ leptomeningeal involvement; were pregnant or lactating women, or were not using effective contraception; had prior bone marrow/stem cell transplantation, relevant cardiac disease, alcohol consumption or cirrhosis, active uncontrolled infection, or any disease interfering with study outcome.

\section{Study treatment}

Patients were treated with doxorubicin $40 \mathrm{mg} / \mathrm{m}^{2}$ as bolus followed by lurbinectedin $2.0 \mathrm{mg} / \mathrm{m}^{2}$ intravenously (i.v.) over one hour on Day $1 \mathrm{q} 3 \mathrm{wk}$. This dose was based on the RD defined during dose escalation (doxorubicin $50 \mathrm{mg} / \mathrm{m}^{2}$ and lurbinectedin $4.0 \mathrm{mg}$ flat dose [FD]) [7], with a reduced doxorubicin dose and the lurbinectedin dose transformed to a BSAbased dose. Both drug doses were capped at a BSA of $2.0 \mathrm{~m}^{2}$. Patients who received ten cycles of the combination or had to discontinue doxorubicin due to a cardiac adverse event were switched to lurbinectedin alone at its single-agent RD defined during the First-in-Human study ( $4.0 \mathrm{mg} / \mathrm{m}^{2}$ on Day $1 \mathrm{q} 3 \mathrm{wk}$ ) to prevent doxorubicin-induced cardiomyopathy $[5,8]$.

Commercially available doxorubicin was provided. Lurbinectedin was supplied as a lyophilized powder concentrate, reconstituted in sterile water for injection, and diluted with glucose $5 \%$ or sodium chloride $0.9 \%$ solution. All patients received standard antiemetic prophylaxis before each infusion. Treatment was given until disease progression, unacceptable toxicity, intercurrent illness precluding study continuation, patient refusal and/or non-compliance with study requirements, treatment delay $>15$ days (except if clear clinical benefit), and requirement of $>2$ dose reductions.

\section{Dose-limiting toxicities}

Protocol guidelines concerning dose feasibility and definition of dose-limiting toxicities (DLTs) that were used during dose escalation in this study also applied to this cohort [7]. The regimen of doxorubicin $40 \mathrm{mg} / \mathrm{m}^{2}$ and lurbinectedin $2.0 \mathrm{mg} /$ $\mathrm{m}^{2}$ on Day $1 \mathrm{q} 3 \mathrm{wk}$ would be considered feasible if less than one third of evaluable patients had DLTs during Cycle 1.

\section{Study assessments}

Hematology and biochemistry tests were conducted at baseline, weekly during Cycle 1, and before each lurbinectedin infusion and on Day 10 during subsequent cycles. Electrocardiograms and LVEF assessments were done at baseline, and were repeated at doxorubicin discontinuation or if clinically indicated.

Antitumor activity was evaluated every two cycles according to the Response Evaluation Criteria In Solid Tumors (RECIST) v.1.1 [9]. Overall response rate (ORR) was the percentage of patients with complete $(\mathrm{CR})$ or partial response (PR), and disease control rate (DCR) was the percentage of patients with response or stable disease (SD). Time-to-event parameters were duration of response (DoR), progression-free survival (PFS) and overall survival (OS).

Adverse events (AEs) and laboratory abnormalities were graded using the National Cancer Institute Common Terminology Criteria for Adverse Events (NCI-CTCAE) v.4 [10], and coded with the Medical Dictionary for Regulatory Activities (MedDRA) v.14.1. 


\section{Statistical analysis}

Continuous variables were presented with summary statistics and categorical variables in frequency tables. Time-to-event variables were calculated using Kaplan-Meier approach. Binomial exact distribution was used to calculate $95 \%$ confidence intervals $(95 \% \mathrm{CIs})$ for categorical variables.

\section{Results}

\section{Dose feasibility}

Forty-seven patients with SCLC or endometrial cancer in this cohort were treated with doxorubicin $40 \mathrm{mg} / \mathrm{m}^{2}$ and lurbinectedin $2.0 \mathrm{mg} / \mathrm{m}^{2}$ on Day $1 \mathrm{q} 3 \mathrm{wk}$. DLTs occurred in four of $46(9 \%)$ evaluable patients (four of 28 [14.3\%] with SCLC), thereby confirming feasibility. DLTs comprised grade $3 / 4$ febrile neutropenia $(n=2)$, grade 4 thrombocytopenia, and grade 3 decreased appetite ( $n=1$ each).

\section{Characteristics of SCLC patients}

Twenty-eight of the 47 patients treated in this cohort had relapsed SCLC. Most of these patients were male $(n=21,75 \%)$ and had an ECOG PS of $1(n=19,68 \%)$ (Table 1). Median age was 64 years (range, 49-77 years). At baseline, 21 (75\%) had bulky disease (target lesion $>50 \mathrm{~mm}$ ). Median number of sites of disease per patient was 3 (range, 1-6 sites). Most common sites of disease were lymph nodes $(n=19,68 \%)$, lung $(n=17,61 \%)$, liver $(n=14,50 \%)$ and bone $(n=9$, $32 \%)$. One patient (4\%) had brain metastases. Eighteen patients $(64 \%)$ had sensitive disease (chemotherapy-free interval $[\mathrm{CTFI}] \geq 90$ days after first-line therapy) and ten patients (36\%) had resistant disease (CTFI $<90$ days, including six patients with refractory disease [CTFI $\leq 30$ days]).

All patients received prior systemic anticancer therapy with platinum compounds and etoposide. Twenty-two patients (79\%) received prior radiotherapy, including 11 patients (39\%) who were given prophylactic cranial irradiation (PCI).

\section{Treatment exposure}

Patients received 140 cycles of the combination (median: 4 cycles [range, 1-10 cycles] per patient). Median doxorubicin cumulative dose per patient was $159.9 \mathrm{mg} / \mathrm{m}^{2}$ (range, 40.0 $406.4 \mathrm{mg} / \mathrm{m}^{2}$ ), and median relative dose intensity was $92.4 \%$ (range, 69.7-105.5\%). For lurbinectedin, median cumulative dose per patient was $7.2 \mathrm{mg} / \mathrm{m}^{2}$ (range, $2.0-20.1 \mathrm{mg} / \mathrm{m}^{2}$ ) and median relative dose intensity was $92.4 \%$ (range, 62.3$105.5 \%)$. Six patients (21\%) received 13 cycles of singleagent lurbinectedin after doxorubicin discontinuation (median: 2 cycles [range, 1-4 cycles] per patient), for a median cumulative dose of $7.6 \mathrm{mg} / \mathrm{m}^{2}$ (range, $2.0-12.8 \mathrm{mg} / \mathrm{m}^{2}$ ) and a median relative dose intensity of $100.2 \%$ (range, 80.2 $101.2 \%)$. Most patients $(n=23,82 \%)$ discontinued treatment due to radiologically confirmed disease progression; no patients discontinued as a result of treatment-related adverse events.

\section{Efficacy}

All treated patients were evaluable for efficacy. Ten patients showed confirmed response $(\mathrm{ORR}=36 \%$ [95\%CI, 18.6$55.9 \%$ ]; one CR [4\%] and nine PR [32\%]) and ten patients (36\%) had SD, for a DCR of $72 \%$ (95\%CI, 51.3-86.8\%). Nine confirmed responses (one CR and eight PR) and six SD occurred among patients with sensitive disease $(\mathrm{ORR}=$ $50 \%$ [95\%CI, 26.0-73.9\%]; DCR $=83 \%$ [95\%CI, 58.696.4\%]). Only one confirmed PR and four SD were found among patients with resistant disease (ORR $=10 \%$ [95\%CI, $0.25-44.5 \%] ;$ DCR $=50 \%$ [95\%CI, 18.7-81.3\%]) (Table 2).

Tumor shrinkage was observed in 18 of $26(69 \%)$ patients with at least one radiological tumor assessment (Fig. 1): 13 of $18(72 \%)$ with sensitive disease and five of eight $(63 \%)$ with resistant disease. Antitumor activity achieved with the combination was maintained in four of six patients treated with single-agent lurbinectedin after doxorubicin discontinuation.

Median DoR was 5.2 months (95\%CI, 1.0-6.9 months) in all patients (sensitive disease: 5.5 months [95\% CI, 1.0 9.5 months]; the single response found in a patient with resistant disease lasted 1.8 months). In all patients, median PFS was 3.3 months (95\%CI, 1.4-6.2 months) (sensitive disease: 5.7 months [95\%CI, 2.6-7.9 months]; resistant disease: 1.3 months [95\% CI, 0.8-3.4 months]) and median OS was 7.9 months (95\%CI, 4.2-11.5 months) (sensitive disease: 11.5 months [95\%CI, 6.0-16.6 months]; resistant disease: 4.6 months [range, $0.8-6.7$ months]). In the 10 responders, median PFS was 6.6 months (95\%CI, 2.6-8,2 months) and median OS was 10.4 months (95\%CI, 7.9-16.6 months).

An exploratory subset efficacy analysis was performed on 22 patients in this cohort who had non-refractory disease (i.e., excluding patients with CTFI $\leq 30$ days after first-line therapy). All ten responses and seven SD occurred among these patients $(\mathrm{ORR}=46 \%$ [95\% CI, 24.4-67.8\%]); $\mathrm{DCR}=77 \%$ [95\%CI, 54.6-92.2\%]). Median PFS was 5.1 months (95\% CI, 1.9-6.7 months) and median OS was 10.2 months (95\% CI, 6.0-11.7 months) (Table 2).

\section{Safety}

All treated patients were evaluable for safety. The most frequent treatment-related AEs or with unknown relationship were fatigue, nausea, decreased appetite, vomiting, and alopecia (Table 3). Most of these AEs were grade $1 / 2$, with the most common grade $\geq 3$ AEs being fatigue (25\%), febrile 
Table 1 Baseline characteristics of patients with relapsed SCLC

\begin{tabular}{|c|c|c|}
\hline & \multicolumn{2}{|c|}{$\begin{array}{l}\text { Doxorubicin } 40 \mathrm{mg} / \mathrm{m}^{2}+\text { lurbinectedin } 2.0 \mathrm{mg} / \mathrm{m}^{2} \\
(n=28)\end{array}$} \\
\hline & $\mathrm{n}$ & $\%$ \\
\hline \multicolumn{3}{|l|}{ Gender } \\
\hline Male & 21 & 75 \\
\hline Female & 7 & 25 \\
\hline Median age (range) (years) & $64.0(49-77)$ & \\
\hline \multicolumn{3}{|l|}{ ECOG performance status } \\
\hline 0 & 9 & 32 \\
\hline 1 & 19 & 68 \\
\hline Median BSA (range) $\left(\mathrm{m}^{2}\right)$ & $1.9(1.5-2.3)$ & \\
\hline \multicolumn{3}{|l|}{ Smoker } \\
\hline Current & 13 & 46 \\
\hline Former & 14 & 50 \\
\hline Never & 1 & 4 \\
\hline Median number of sites of disease involvement (range) & $3.0(1-6)$ & \\
\hline \multicolumn{3}{|l|}{ Metastasis at baseline } \\
\hline Lymph nodes & 19 & 68 \\
\hline Lung & 17 & 61 \\
\hline Liver & 14 & 50 \\
\hline Bone & 9 & 32 \\
\hline Pleura & 6 & 21 \\
\hline Adrenal & 5 & 18 \\
\hline CNS & 1 & 4 \\
\hline Bulky disease (any target lesion $>50 \mathrm{~mm}$ ) & 21 & 75 \\
\hline \multicolumn{3}{|l|}{ Prior therapy } \\
\hline Systemic therapy & 28 & 100 \\
\hline Chemotherapy & 28 & 100 \\
\hline Biological therapy & 2 & 7 \\
\hline Radiotherapy & 22 & 79 \\
\hline PCI & 11 & 39 \\
\hline \multicolumn{3}{|l|}{ Prior anticancer agents } \\
\hline Platinum compounds & 28 & 100 \\
\hline Podophyllotoxin derivatives & 28 & 100 \\
\hline \multicolumn{3}{|l|}{ CTFI } \\
\hline$\geq 90$ days & 18 & 64 \\
\hline$<90$ days & 10 & 36 \\
\hline TTP from diagnosis to first infusion (months) & $8.4(3.9-19.8)$ & \\
\hline TTP to last prior therapy (months) & $6.8(1.0-18.9)$ & \\
\hline
\end{tabular}

$B S A$, body surface area; $C N S$, central nervous system; $C T F I$, chemotherapy-free interval; ECOG, Eastern Cooperative Oncology Group; $P C I$, prophylactic cranial irradiation; $S C L C$, small cell lung cancer; TTP, time to progression neutropenia (14\%) and nausea (7\%). The only treatmentrelated $\mathrm{AE}$ to reach grade 4 was febrile neutropenia, in two patients. One episode of grade 5 treatment-related neutropenic infection occurred in one patient with ongoing diabetes, atrial fibrillation and chronic obstructive pulmonary disease, and disease involvement in the brain and lungs. No treatment- related cardiac adverse events associated with the LVEF occurred.

Regardless of relationship, most laboratory abnormalities were grade $1 / 2$. Grade $\geq 3$ hematological abnormalities comprised anemia, neutropenia (grade 4 episodes lasting a median of 3 days [range, 1-6 days]), leukopenia, and 
Table 2 Best tumor response according to Response Evaluation Criteria In Solid Tumors (RECIST) in patients with relapsed SCLC treated with doxorubicin $40 \mathrm{mg} / \mathrm{m}^{2}$ and lurbinectedin $2.0 \mathrm{mg} / \mathrm{m}^{2}$ on Day $1 \mathrm{q} 3 \mathrm{wk}$

\begin{tabular}{|c|c|c|c|c|c|c|c|c|}
\hline & \multicolumn{8}{|c|}{ Doxorubicin $40 \mathrm{mg} / \mathrm{m}^{2}+$ lurbinectedin $2.0 \mathrm{mg} / \mathrm{m}^{2}$} \\
\hline & \multicolumn{6}{|c|}{ All patients with relapsed SCLC } & \multicolumn{2}{|c|}{$\begin{array}{l}\text { Patients with relapsed, non-refractory SCLC } \\
(n=22)\end{array}$} \\
\hline & \multicolumn{2}{|c|}{$\begin{array}{l}\mathrm{CTFI} \geq 90 \text { days } \\
(n=18)\end{array}$} & \multicolumn{2}{|c|}{$\begin{array}{l}\text { CTFI }<90 \text { days } \\
(n=10)\end{array}$} & \multicolumn{2}{|c|}{$\begin{array}{l}\text { Total } \\
(n=28)\end{array}$} & \multirow[b]{2}{*}{$\mathrm{n}$} & \multirow[b]{2}{*}{$\%$} \\
\hline & $\mathrm{n}$ & $\%$ & $\mathrm{n}$ & $\%$ & $\mathrm{n}$ & $\%$ & & \\
\hline $\mathrm{CR}$ & 1 & 6 & . & . & 1 & 4 & 1 & 5 \\
\hline PR & 8 & 44 & 1 & 10 & 9 & 32 & 9 & 41 \\
\hline SD & 6 & 33 & 4 & 40 & 10 & 36 & 7 & 32 \\
\hline$\geq 4$ months & 3 & 17 & 1 & 10 & 4 & 14 & 3 & 14 \\
\hline$<4$ months & 3 & 17 & 3 & 30 & 6 & 21 & 4 & 18 \\
\hline PD & 3 & 17 & 5 & 50 & 8 & 29 & 5 & 19 \\
\hline ORR $(95 \% \mathrm{CI})$ & \multicolumn{2}{|c|}{$\begin{array}{l}50 \% \\
(26.0-73.9 \%)\end{array}$} & \multicolumn{2}{|c|}{$\begin{array}{l}10 \% \\
(0.25-44.5 \%)\end{array}$} & \multicolumn{2}{|c|}{$\begin{array}{l}36 \% \\
(18.6-55.9 \%)\end{array}$} & \multicolumn{2}{|l|}{$\begin{array}{l}46 \% \\
(24.4-67.8 \%)\end{array}$} \\
\hline DCR $(95 \% \mathrm{CI})$ & \multicolumn{2}{|c|}{$\begin{array}{l}83 \% \\
(58.6-96.4 \%)\end{array}$} & \multicolumn{2}{|c|}{$\begin{array}{l}50 \% \\
(18.7-81.3 \%)\end{array}$} & \multicolumn{2}{|c|}{$\begin{array}{l}72 \% \\
(51.3-86.8 \%)\end{array}$} & \multicolumn{2}{|l|}{$\begin{array}{l}77 \% \\
(54.6-92.2 \%)\end{array}$} \\
\hline Median DoR (months) (95\%CI) & \multicolumn{2}{|c|}{$\begin{array}{l}5.5 \\
(1.0-9.5)\end{array}$} & \multicolumn{2}{|c|}{$\begin{array}{l}1.8 \\
(-)\end{array}$} & \multicolumn{2}{|c|}{$\begin{array}{l}5.2 \\
(1.0-6.9)\end{array}$} & \multicolumn{2}{|l|}{$\begin{array}{l}5.2 \\
(1.0-6.9)\end{array}$} \\
\hline Median PFS (months) (95\%CI) & \multicolumn{2}{|c|}{$\begin{array}{l}5.7 \\
(2.6-7.9)\end{array}$} & \multicolumn{2}{|c|}{$\begin{array}{l}1.3 \\
(0.8-3.4)\end{array}$} & \multicolumn{2}{|c|}{$\begin{array}{l}3.3 \\
(1.4-6.2)\end{array}$} & \multicolumn{2}{|l|}{$\begin{array}{l}5.1 \\
(1.9-6.7)\end{array}$} \\
\hline Median OS (months) (95\%CI) & \multicolumn{2}{|c|}{$\begin{array}{l}11.5 \\
(6.0-16.6)\end{array}$} & \multicolumn{2}{|c|}{$\begin{array}{l}4.6 \\
(0.8-6.7)\end{array}$} & \multicolumn{2}{|c|}{$\begin{array}{l}7.9 \\
(4.2-11.5)\end{array}$} & \multicolumn{2}{|l|}{$\begin{array}{l}10.2 \\
(6.0-11.7)\end{array}$} \\
\hline
\end{tabular}

${ }^{\text {a }}$ Excludes patients with $\mathrm{CTFI} \leq 30$ days after first-line therapy

$C I$, confidence interval; $C R$, complete response; $C T F I$, chemotherapy-free interval; $D C R$, disease control rate; $D o R$, duration of response; $O R R$, overall response rate; $O S$, overall survival; $P D$, progressive disease; $P F S$, progression-free survival; $P R$, partial response; $\mathrm{q} 3 \mathrm{wk}$, every three weeks; $S C L C$, small cell lung cancer; $S D$, stable disease

thrombocytopenia (Table 3). The most common biochemical abnormalities were creatinine and transaminase increases. Grade $\geq 3$ biochemical abnormalities consisted of transaminase increases in one patient with normal levels and no liver metastases at baseline, and grade 4 creatinine increase in one patient that was concomitant with severe renal failure unrelated to treatment.

Sixteen patients $(57 \%)$ required granulocyte colonystimulating factor support, seven (25\%) were given red blood cell transfusions, and three $(11 \%)$ received platelet transfusions. Eighteen dosing delays, seven lurbinectedin dose reductions and one doxorubicin dose reduction were the result of treatment-related AEs. Twenty-two patients died during the study, mostly $(n=21)$ due to disease progression and one due to treatment-related neutropenic infection.

The most common AEs related to single-agent lurbinectedin in the six patients who remained on treatment after doxorubicin discontinuation were fatigue (all patients), nausea $(n=4 ; 67 \%)$, dizziness and dyspnea $(n=3$ each; $50 \%)$. Most of these AEs were grade 1/2. Grade 3/4 hematological abnormalities consisted of neutropenia, thrombocytopenia, leukopenia (50\% of patients each), and anemia (33\%). All biochemical abnormalities were grade 1 .

\section{Discussion}

A regimen of doxorubicin $40 \mathrm{mg} / \mathrm{m}^{2}$ and lurbinectedin $2.0 \mathrm{mg} / \mathrm{m}^{2}$ on Day $1 \mathrm{q} 3 \mathrm{wk}$ showed noteworthy antitumor activity in patients with relapsed SCLC included in an expansion cohort of a phase 1 study evaluating the doxorubicin/ lurbinectedin combination in advanced solid tumors. ORR was $36 \%$, with median DoR 5.2 months, median PFS 3.3 months and median OS 7.9 months. Most responses and longer median time-to-event parameters were found among patients with sensitive disease (ORR $=50 \%$, DoR 5.5 months, PFS 5.7 months, OS 11.5 months). In contrast, patients with resistant disease only had one response $(\mathrm{ORR}=10 \%$, DoR 1.8 months) and shorter median survival times (PFS 1.3 months, OS 4.6 months). Of note, all responses occurred among patients with non-refractory disease $(\mathrm{ORR}=46 \%$, PFS 5.1 months, OS 10.2 months). 


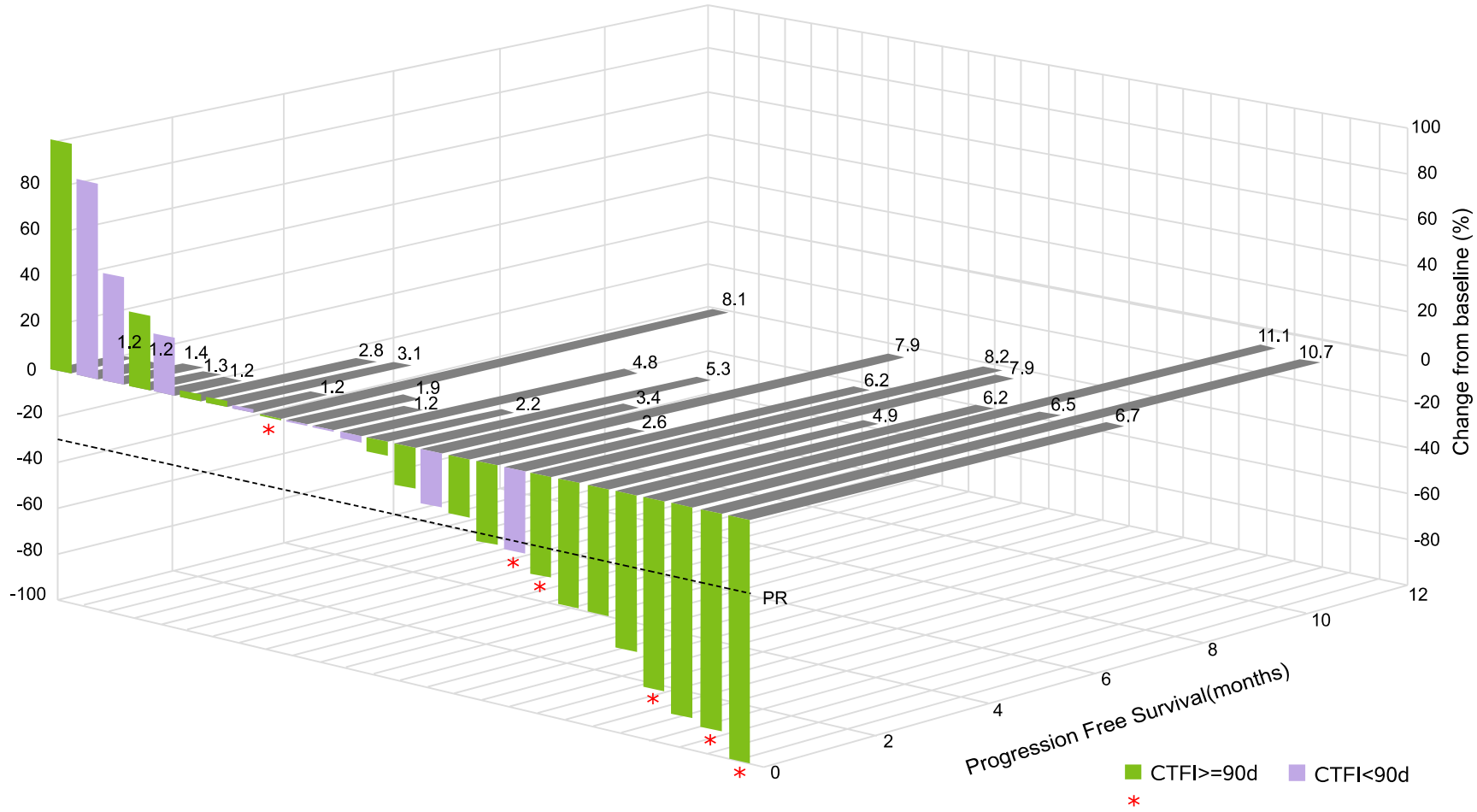

Fig. 1 Waterfall plot showing maximum variation of target lesions and progression-free survival in patients with at least one radiological tumor assessment $(n=26)$. Ten patients had target lesion decrease $>30 \%$ : one

Treatment and survival of patients with SCLC has not changed substantially over the last two decades. Response rates to first-line therapy are high, but recurrence is frequent, especially in patients with extensive-stage disease [11, 12]. Topotecan is the only second-line therapy approved in the U.S. for patients with sensitive SCLC [12]. However, use of topotecan is challenging because of associated hematological toxicity and modest clinical benefit (ORR $=5-24 \%$; median OS 6-8 months) [13-20]. Similar results have been reported for cyclophosphamide, doxorubicin and vincristine (CAV), a combination also used in second-line treatment of SCLC [13]. Alternative therapies such as monoclonal antibodies (nivolumab, atezolizumab) [21, 22] have also been evaluated for relapsed SCLC, but to date none have shown superiority over currently approved therapies.

The results obtained in this study with the doxorubicin/ lurbinectedin combination compare favorably with those reported with second-line therapies for relapsed SCLC. Higher ORRs were achieved with the combination, both at the RD of doxorubicin $50 \mathrm{mg} / \mathrm{m}^{2}$ and lurbinectedin $4.0 \mathrm{mg}$ FD defined during dose escalation (overall: $65 \%$; sensitive disease: $89 \%$; resistant disease: $38 \%$ ) [7] and in the expansion cohort at the reduced dose of doxorubicin $40 \mathrm{mg} / \mathrm{m}^{2}$ and lurbinectedin $2.0 \mathrm{mg} / \mathrm{m}^{2}$ (overall: $36 \%$; sensitive disease: $50 \%$; resistant disease: $10 \%$ ). Median survival times were also longer, especially in sensitive disease (PFS 5.8 months at the RD [7]; PFS 5.7 months and OS 11.5 months in the expansion cohort). In with $\mathrm{CR}$ and nine with PR. Red stars = treatment switch to lurbinectedin alone. CR, complete response; CTFI, chemotherapy-free interval; $d$, days; $\mathrm{PR}$, partial response

the expansion cohort, exclusion of patients with refractory disease (CTFI $\leq 30$ days; a population usually not included in clinical trials due to having a poorer prognosis) increased the ORR to $46 \%$ and also resulted in long median survival times (PFS 5.1 months, OS 10.2 months). Of note, results from a cohort of 105 patients treated with single-agent lurbinectedin in a multicenter, multinational phase II Basket trial showed that lurbinectedin is active as second-line therapy in relapsed SCLC (ORR $=35 \%$; median OS 9.3 months). Antitumor activity in this cohort was notable, both in sensitive $(\mathrm{ORR}=45 \%)$ and resistant disease $(\mathrm{ORR}=22 \%)[23,24] . \mathrm{Of}$ note, $20 \%$ of patients treated with single-agent lurbinectedin in this phase II Basket study had refractory disease (CTFI $<30$ days).

Treatment with the doxorubicin/lurbinectedin combination was generally well tolerated, and was primarily associated with manageable and predictable myelotoxicity. Compared with the RD defined during dose escalation, patients in the expanded cohort showed less grade 4 neutropenia (68\% vs. $79 \%$ ), grade 3 anemia (25\% vs. $47 \%$ ) and treatment-related febrile neutropenia (14\% vs. 26\%) [7]. Biochemical abnormalities were mostly mild or moderate and asymptomatic, and occurred at similar frequencies in the two cohorts. Some treatment-related non-hematological adverse events (mucositis, $18 \%$ vs. 53\%; alopecia, $25 \%$ vs. $42 \%$ ) were less common in the expansion cohort than at the RD, while others occurred at similar 
Table 3 Treatment-related adverse events $(\geq 10 \%$ of patients or grade $\geq 3)$, and laboratory abnormalities regardless of relationship, in patients with relapsed SCLC treated with doxorubicin $40 \mathrm{mg} / \mathrm{m}^{2}$ and lurbinectedin $2.0 \mathrm{mg} / \mathrm{m}^{2}$ on Day $1 \mathrm{q} 3 \mathrm{wk}$

\begin{tabular}{|c|c|c|c|c|c|c|c|c|}
\hline & \multicolumn{8}{|c|}{$\begin{array}{l}\text { Doxorubicin } 40 \mathrm{mg} / \mathrm{m}^{2}+\text { lurbinectedin } 2.0 \mathrm{mg} / \mathrm{m}^{2} \\
(\mathrm{n}=28)\end{array}$} \\
\hline & \multicolumn{8}{|c|}{ NCI-CTCAE grade } \\
\hline & \multicolumn{2}{|l|}{3} & \multicolumn{2}{|l|}{4} & \multicolumn{2}{|l|}{5} & \multicolumn{2}{|l|}{ All } \\
\hline & $\mathrm{n}$ & $\%$ & $\mathrm{n}$ & $\%$ & $\mathrm{n}$ & $\%$ & $\mathrm{n}$ & $\%$ \\
\hline \multicolumn{9}{|l|}{ Treatment-related AEs } \\
\hline Alopecia & . & . & . & . & . & . & 7 & 25 \\
\hline Constipation & . & . & . & . & . & . & 5 & 18 \\
\hline Decreased appetite & 1 & 4 & . & . & . & . & 13 & 46 \\
\hline Dizziness & . & . & . & . & . & . & 3 & 11 \\
\hline Dysesthesia & . & . & . & . & . & . & 3 & 11 \\
\hline Dysgeusia & . & . & . & . & . & . & 3 & 11 \\
\hline Fatigue & 7 & 25 & . & . & . & . & 22 & 79 \\
\hline Febrile neutropenia & 2 & 7 & 2 & 7 & . & . & 4 & 14 \\
\hline Hypertension & 1 & 4 & . & . & . & . & 1 & 4 \\
\hline Mucositis & . & . & . & . & . & . & 5 & 18 \\
\hline Nausea & 2 & 7 & . & . & . & . & 19 & 68 \\
\hline Neutropenic infection & . & . & . & . & 1 & 4 & 1 & 4 \\
\hline Vomiting & . & . & . & . & . & . & 11 & 39 \\
\hline \multicolumn{9}{|c|}{ Hematological abnormalities } \\
\hline Anemia & 7 & 25 & . & . & . & . & 27 & 96 \\
\hline Leukopenia & 14 & 50 & 9 & 32 & . & . & 26 & 93 \\
\hline Neutropenia & 7 & 25 & 19 & 68 & . & . & 27 & 96 \\
\hline Thrombocytopenia & 3 & 11 & 3 & 11 & . & . & 18 & 64 \\
\hline \multicolumn{9}{|c|}{ Biochemical abnormalities } \\
\hline ALP increased & . & . & . & . & . & . & 12 & 43 \\
\hline ALT increased & 1 & 4 & . & . & . & . & 12 & 43 \\
\hline AST increased & . & . & 1 & 4 & . & . & 9 & 32 \\
\hline Bilirubin increased & . & . & . & . & . & . & 6 & 21 \\
\hline Creatinine increased & . & . & 1 & 4 & . & . & 23 & 82 \\
\hline
\end{tabular}

$A E$, adverse event; $A L P$, alkaline phosphatase; $A L T$, alanine aminotransferase; $A S T$, aspartate aminotransferase; $N C I-C T C A E$, National Cancer Institute Common Terminology Criteria for Adverse Events; q3wk, every three weeks; $S C L C$, small cell lung cancer

frequencies (fatigue, $79 \%$ in both cohorts; nausea/ vomiting, $39-68 \%$ vs. $58 \%$; decreased appetite, $46 \%$ vs. $53 \%$ ) [7]. No patients in either cohort discontinued treatment with the combination due to treatment-related events. Of note, the absence of treatment-related cardiac events associated with the LVEF either during dose escalation or in the expansion cohort suggested that lurbinectedin does not increase ventricular dysfunction over doxorubicin. The safety profile of single-agent lurbinectedin in the expansion cohort is in agreement with that reported elsewhere $[5,23]$.

In summary, remarkable antitumor activity has been found for a combination of doxorubicin $40 \mathrm{mg} / \mathrm{m}^{2}$ and lurbinectedin $2.0 \mathrm{mg} / \mathrm{m}^{2}$ on Day $1 \mathrm{q} 3 \mathrm{wk}$ in an expanded cohort of patients with relapsed SCLC, particularly in sensitive disease, and higher than that reported for currently approved second-line therapies. Compared to this dose, the initial RD defined in this study (doxorubicin $50 \mathrm{mg} / \mathrm{m}^{2}$ and lurbinectedin $4.0 \mathrm{mg}$ FD) resulted in a higher ORR but also higher toxicity, with more frequent hematological abnormalities and treatment-related mucositis and alopecia. Of note, single-agent lurbinectedin has recently been approved by the U.S. Food and Drug Administration for the treatment of adult patients with metastatic SCLC with disease progression on or after platinum-based chemotherapy. An ongoing open-label, 
randomized phase III trial is evaluating the doxorubicin/ lurbinectedin combination vs. standard-of-care chemotherapy (CAV or topotecan) in patients with SCLC and CTFI $\geq 30$ days that has progressed after one line of platinum-based chemotherapy [25].

Acknowledgements The authors would like to thank all the patients (and their families) who participated in this study.

Authors' contributions M.E.O., M. Forster, V.M., M.P.L-C., I.B., M. Flynn, B.D. and M.d.M. collected and interpreted data, critically reviewed the paper drafts and provided final approval of the paper to be published. E.C. helped conceive the design of the study, collected and interpreted data, critically reviewed the paper drafts and provided final approval of the paper to be published. J.A.L-V. analyzed and interpreted data, contributed to the initial writing of the paper, critically reviewed the paper drafts and provided final approval of the paper to be published. R.N. and A.Z. analyzed and interpreted data, critically reviewed the paper drafts and provided final approval of the paper to be published. C.K. helped conceive the design of the study, analyzed and interpreted data, critically reviewed the paper drafts and provided final approval of the paper to be published. M.C-Y. analyzed and interpreted data, contributed to the initial writing of the paper, critically reviewed the paper drafts and provided final approval of the paper to be published.

Funding This work was supported by Pharma Mar, S.A.

Data availability Individual participant data are not publicly available since this requirement was not anticipated in the study protocol considering that this trial started patient enrolment in 2011. Clinical trial summary results were placed in the European Clinical Trials Database (EudraCT; https://eudract.ema.europa.eu).

\section{Declarations}

Conflicts of interest/competing interests Martin Forster has conducted consulting and advisory services, speaking or writing engagements, or public presentations for Achilles, AstraZeneca, Bayer, BMS, Celgene, Guardant Health, Merck, MSD, Nanobiotix, Novartis, Oxford VaMedix, Pfizer, Pfizer, Roche and Takeda; his institution has received research funding from AstraZeneca, Boehringer Ingelheim, MSD and Merck; in addition, Martin Foster is supported by the UCL/UCLH NIHR Biomedical Research Centre and runs early phase studies in the NIHR UCLH Clinical Research Facility supported by the UCL ECMC. Emiliano Calvo has had a company leadership role, employment relationship or ownership interest for START Madrid, Oncoart Associated, International Cancer Consultants and HM Hospitals Group; has conducted consulting and advisory services, speaking or writing engagements, or public presentations for Astellas Pharma, Novartis, Nanobiotix, Pfizer, Janssen, GLG, Merck, Medscape, BMS, Pierre-Fabre, Gilead, Cerulean, Gehrman Consulting, Boehringen-Ingelheim, Seattle Genetics, Guidepoint, AstraZeneca, Roche/Genetech, PsiOxus, Abbvie, Celgene, Servier and Amcure; has been study international principal investigator for AstraZeneca and member of study steering committees for Novartis and BeiGene, and his institution has received financial support from Abbvie, Amgen, AstraZeneca, Bayer, Boehringer Ingelheim, BristolMyers Squibb, Eisai, Janssen Oncology, Hospira, Lilly, Merck, Merus, Millennium, Nanobiotix, Nektar. Novartis, OncoMed, Pfizer, PharmaMar, PsiOxus Therapeutics, Puma Biotechnology, Regeneron, Roche-Genentech, Sanofi, Spectrum Pharmaceuticals, ACEA Bio, Amcure, Cytomx, H3-Biomedicine, Incyte, Kura, LOXO, Macrogenics, Menarini, Principia, Tahio, Tesaro, BeiGene, Transgene, Takeda, Innovio, MSD, Seattle Genetics, Mersana, GSK, Daiichi, Astellas,
ORCA, Boston Therapeutics, Dynavax, DebioPharma, Synthon and Rigontec. José Antonio López-Vilariño, Rafael Núñez, Carmen Kahatt and Ali Zeaiter are employees and stock owners of Pharma Mar, S.A. Martin Cullell-Young is an employee of Pharma Mar, S.A. All remaining authors have declared no conflicts of interest.

Ethics approval The study was approved by the Research Ethics Committees of participating centers in Spain and the U.K. The study was conducted in full accordance with the principles of the World Medical Association Declaration of Helsinki, the International Conference of Harmonisation, and all applicable local guidelines and regulations on good clinical practice.

Consent to participate All patients provided written informed consent to participate in this study.

Consent for publication All patients provided written informed consent about participation in this study and the use of collated data. No individual patient data are included in this article that could be used to identify any individual.

Code availability Not applicable.

Open Access This article is licensed under a Creative Commons Attribution 4.0 International License, which permits use, sharing, adaptation, distribution and reproduction in any medium or format, as long as you give appropriate credit to the original author(s) and the source, provide a link to the Creative Commons licence, and indicate if changes were made. The images or other third party material in this article are included in the article's Creative Commons licence, unless indicated otherwise in a credit line to the material. If material is not included in the article's Creative Commons licence and your intended use is not permitted by statutory regulation or exceeds the permitted use, you will need to obtain permission directly from the copyright holder. To view a copy of this licence, visit http://creativecommons.org/licenses/by/4.0/.

\section{References}

1. Leal JF, Martinez-Diez M, Garcia-Hernandez V, Moneo V, Domingo A, Bueren-Calabuig JA, Negri A, Gago F, GuillenNavarro MJ, Aviles P, Cuevas C, Garcia-Fernandez LF, Galmarini CM (2010) PM01183, a new DNA minor groove covalent binder with potent in vitro and in vivo anti-tumour activity. $\mathrm{Br} \mathrm{J}$ Pharmacol 161(5):1099-1110

2. Santamaria Nunez G, Robles CM, Giraudon C, Martinez-Leal JF, Compe E, Coin F, Aviles P, Galmarini CM, Egly JM (2016) Lurbinectedin specifically triggers the degradation of phosphorylated RNA polymerase II and the formation of DNA breaks in cancer cells. Mol Cancer Ther 15(10):1-14

3. Harlow ML, Maloney N, Roland J, Guillen Navarro MJ, Easton MK, Kitchen-Goosen SM, Boguslawski EA, Madaj ZB, Johnson BK, Bowman MJ, D'incalci M, Winn ME, Turner L, Hostetter G, Galmarini CM, Aviles PM, Grohar PJ (2016) Lurbinectedin inactivates the Ewing sarcoma oncoprotein EWS-FLI1 by redistributing it within the nucleus. Cancer Res 76(22):6657-6668

4. Belgiovine C, Bello E, Liguori M, Craparotta I, Mannarino L, Paracchini L, Beltrame L, Marchini S, Galmarini CM, Mantovani A, Frapolli R, Allavena P, D'incalci M (2017) Lurbinectedin reduces tumour-associated macrophages and the inflammatory tumour microenvironment in preclinical models. Br J Cancer 117(5):628-638 
5. Elez ME, Tabernero J, Geary D, Macarulla T, Kang SP, Kahatt C, Pita AS, Teruel CF, Siguero M, Cullell-Young M, Szyldergemajn S, Ratain MJ (2014) First-in-human phase I study of Lurbinectedin (PM01183) in patients with advanced solid tumors. Clin Cancer Res 20(8):2205-2214

6. Guillen MJ, Cataluña O, Palomares M, Lopez R, Nuñez P, Cuevas $\mathrm{C}$ and Aviles $\mathrm{P}$ (2015) Lurbinectedin (PM01183) synergizes in vivo the antitumor activity of doxorubicin in SCLC tumor xenografts. In: Proceedings of the 106th Annual Meeting of the American Association for Cancer Research; 2015 Apr 18-22; Philadelphia, PA. Philadelphia (PA): AACR. Cancer Res 75(15 Suppl): Abstract 2542

7. Calvo E, Moreno V, Flynn M, Holgado E, Olmedo ME, Lopez Criado MP, Kahatt C, Lopez-Vilarino JA, Siguero M, FernandezTeruel C, Cullell-Young M, Soto Matos-Pita A, Forster M (2017) Antitumor activity of lurbinectedin (PM01183) and doxorubicin in relapsed small-cell lung cancer: results from a phase I study. Ann Oncol 28(10):2559-2566

8. Von Hoff DD, Layard MW, Basa P, Davis HL Jr, Von Hoff AL, Rozencweig M, Muggia FM (1979) Risk factors for doxorubicininduced congestive heart failure. Ann Intern Med 91(5):710-717

9. Eisenhauer EA, Therasse P, Bogaerts J, Schwartz LH, Sargent D, Ford R, Dancey J, Arbuck S, Gwyther S, Mooney M, Rubinstein L, Shankar L, Dodd L, Kaplan R, Lacombe D, Verweij J (2009) New response evaluation criteria in solid tumours: revised RECIST guideline (version 1.1). Eur J Cancer 45(2):228-247

10. D'incalci M, Badri N, Galmarini CM, Allavena P (2014) Trabectedin, a drug acting on both cancer cells and the tumour microenvironment. Br J Cancer 111(4):646-650

11. Fruh M, De Ruysscher D, Popat S, Crino L, Peters S, Felip E and Group EGW (2013) Small-cell lung cancer (SCLC): ESMO clinical practice guidelines for diagnosis, treatment and follow-up. Ann Oncol 24(Suppl 6):vi99-v105

12. NCCN Clinical practice guidelines in oncology. Small Cell Lung Cancer https://www.nccn.org/professionals/physician_gls/pdf/sclc. pdf.

13. Von Pawel J, Schiller JH, Shepherd FA, Fields SZ, Kleisbauer JP, Chrysson NG, Stewart DJ, Clark PI, Palmer MC, Depierre A, Carmichael J, Krebs JB, Ross G, Lane SR, Gralla R (1999) Topotecan versus cyclophosphamide, doxorubicin, and vincristine for the treatment of recurrent small-cell lung cancer. J Clin Oncol 17(2):658-667

14. O'brien ME, Ciuleanu TE, Tsekov H, Shparyk Y, Cucevia B, Juhasz G, Thatcher N, Ross GA, Dane GC, Crofts T (2006) Phase III trial comparing supportive care alone with supportive care with oral topotecan in patients with relapsed small-cell lung cancer. J Clin Oncol 24(34):5441-5447

15. Horita N, Yamamoto M, Sato T, Tsukahara T, Nagakura H, Tashiro K, Shibata Y, Watanabe H, Nagai K, Inoue M, Nakashima K, Ushio R, Shinkai M, Kudo M and Kaneko T (2015) Topotecan for relapsed small-cell lung cancer: systematic review and metaanalysis of 1347 patients. Sci Rep 5(15437

16. Von Pawel J, Gatzemeier U, Pujol JL, Moreau L, Bildat S, Ranson M, Richardson G, Steppert C, Riviere A, Camlett I, Lane S, Ross G (2001) Phase II comparator study of oral versus intravenous topotecan in patients with chemosensitive small-cell lung cancer. J Clin Oncol 19(6):1743-1749

17. Von Pawel J, Jotte R, Spigel DR, O'brien ME, Socinski MA, Mezger J, Steins M, Bosquee L, Bubis J, Nackaerts K, Trigo JM, Clingan P, Schutte W, Lorigan P, Reck M, Domine M, Shepherd
FA, Li S, Renschler MF (2014) Randomized phase III trial of amrubicin versus topotecan as second-line treatment for patients with small-cell lung cancer. J Clin Oncol 32(35):4012-4019

18. Evans TL, Cho BC, Udud K, Fischer JR, Shepherd FA, Martinez P, Ramlau R, Syrigos KN, Shen L, Chadjaa M, Wolf M (2015) Cabazitaxel versus topotecan in patients with small-cell lung cancer with progressive disease during or after first-line platinum-based chemotherapy. J Thorac Oncol 10(8):1221-1228

19. Eckardt JR, Von Pawel J, Pujol JL, Papai Z, Quoix E, Ardizzoni A, Poulin R, Preston AJ, Dane G, Ross G (2007) Phase III study of oral compared with intravenous topotecan as second-line therapy in small-cell lung cancer. J Clin Oncol 25(15):2086-2092

20. Baize N, Monnet I, Greillier L, Geier M, Lena H, Janicot H, Vergnenegre A, Crequit J, Lamy R, Auliac JB, Le Treut J, Le Caer H, Gervais R, Dansin E, Madroszyk A, Renault P, Legarff G, Schott R, Saulnier P and Chouaid C (2019) Carboplatinetoposide versus topotecan as second-line treatment for sensitive relapsed small-cell lung cancer: phase 3 trial (ID 546). in IASLC; 2019 World Conference on Lung Cancer; September 7-10, Barcelona, Spain

21. Reck M, Vicente D, Ciuleanu T, Gettinger S, Peters S, Horn L, Audigier-Valette C, Pardo N, Juan-Vidal O, Cheng Y, Zhang H, Shi M, Wolf J, Antonia SJ, Nakagawa K, Selvaggi G, Baudelet C, Chang H, Spigel DR (2018) Efficacy and safety of nivolumab (nivo) monotherapy versus chemotherapy (chemo) in recurrent small cell lung cancer (SCLC): Results from CheckMate 331. Ann Oncol 29(Suppl 10):x39-x43

22. Pujol JL, Greillier L, Audigier-Valette C, Moro-Sibilot D, Uwer L, Hureaux J, Guisier F, Carmier D, Madelaine J, Otto J, Gounant V, Merle P, Mourlanette P, Molinier O, Renault A, Rabeau A, Antoine M, Denis MG, Bommart S, Langlais A, Morin F, Souquet PJ (2019) A randomized non-comparative phase II study of anti-programmed cell death-ligand 1 atezolizumab or chemotherapy as second-line therapy in patients with small cell lung cancer: results from the IFCT-1603 trial. J Thorac Oncol 14(5):903-913

23. Trigo J, Subbiah V, Besse B, Moreno V, Lopez R, Sala MA, Peters S, Ponce S, Fernandez C, Alfaro V, Gomez J, Kahatt C, Zeaiter A, Zaman K, Boni V, Arrondeau J, Martinez M, Delord JP, Awada A, Kristeleit R, Olmedo ME, Wannesson L, Valdivia J, Rubio MJ, Anton A, Sarantopoulos J, Chawla SP, Mosquera-Martinez J, D'arcangelo M, Santoro A, Villalobos VM, Sands J, Paz-Ares L (2020) Lurbinectedin as second-line treatment for patients with small-cell lung cancer: a single-arm, open-label, phase 2 basket trial. Lancet Oncol 21(5):645-654

24. Paz-Ares L, Trigo JM, Besse B, Moreno V, Lopez R, Sala MA, Ponce S, Fernandez C, Siguero M, Kahatt C, Zeaiter A, Zaman K, Boni V, Arrondeau J, Martinez M, Delord JP, Awada A, Kristeleit R, Olmedo ME, Subbiah V (2019) Efficacy and safety profile of lurbinectedin in second-line SCLC patients: results from a phase II single-agent trial. J Clin Oncol 37(suppl):Abstract 8506

25. Farago AF, Drapkin BJ, Lopez-Vilarino De Ramos JA, Galmarini CM, Nunez R, Kahatt C, Paz-Ares L (2019) ATLANTIS: a phase III study of lurbinectedin/doxorubicin versus topotecan or cyclophosphamide/doxorubicin/vincristine in patients with small-cell lung cancer who have failed one prior platinum-containing line. Future Oncol 15(3):231-239

Publisher's note Springer Nature remains neutral with regard to jurisdictional claims in published maps and institutional affiliations. 